\title{
Effect of pre-processing of trout by freezing on the characteristics of smoked trout fillets
}

\author{
Pavlićević Nataša ${ }^{1}$, Đorđević Vesna ${ }^{2}$, Dimitrijević Mirjana ${ }^{3}$,Karabasil Neđeljko ${ }^{3}$, Baltić Ž. Milan ${ }^{3}$, \\ Bošković Marija ${ }^{3}$, Petrović Jelena ${ }^{4}$
}

A b s tra $\mathrm{c}$ : In the situation when the capacities of production and further treatment of smoked fish are insufficient, it is necessary to freeze fresh fish during the fishing season and treat it later, when the season is over. That was the reason why the aim of our study was to explore effects of freezing on certain quality parameters of smoked fish. Experimental design included trout separated into two groups: the control group of fresh fish and the experimental group of frozen fish. During production process, total bacterial count was examined, and at the end of the process, chemical composition of the final product (vacuum-packed cold smoked trout) was determined. During the storage of the product at $4^{\circ} \mathrm{C}$ up to 21 days, microbiological, physicochemical and sensory analyses were performed at regular intervals. Overall, the results of the present study demonstrated that pre-processing freezing of trout is suitable and, in periods of large catches, even recommendable step in smoked trout production, at least for smaller processors.

Key words: cold smoking, storage, quality.

\section{Introduction}

Smoked fish is a ready-to-eat product, consumption of which had increased considerably in the last decade in many European countries (GallartJornet et al., 2007). In 2009, more than 121 million tonnes of world fish production was used for direct human consumption. 57 million tonnes, (46.8\%), of the fish intended for human consumption was in live and fresh form. 65 million tonnes, (53.2\%), of the world's fish production underwent some form of processing. About 35 million tonnes, (28.6\%) of the total processed fish was used for manufacturing products for direct human consumption in frozen state, followed by canned fish, about 17.5 million tonnes $(14.4 \%)$, and smoked fish, about 12.4 million tonnes $(10.2 \%)$, (Anon, 2009). This was accompanied by a significant increase in production of farmed salmon (Atlantic salmon), (Cardinal et al., 2001). At the time, nearly $40-50 \%$ of the European farmed salmon was consumed as a cold-smoked product (Røra et al., 1999). For example, each year 45,000 tons of farmed salmon are used in France to produce 18,000 tons of smoked salmon, $15 \%$ of which is exported in Italy, Belgium and Germany (Cardinal et al., 2004). Production of smoked fish and especially smoked salmon is one of the most important sectors in European fishery nowadays. Although smoked salmon was earlier considered as a "luxury" food item, it is now more a product of general consumption. In Serbia, within such type of fish products, smoked trout (Salmo gairdneri) and smoked carp (Cyprinus carpio) are becoming particularly and increasingly popular, so there is a significant market demand for these products.

Production and retailing of cold smoked fish is a complex multi-step process, including salting, smoking, packaging in vacuum or modified atmosphere packaging MAP (Babić et al., 2009; Milijašević et al., 2010), and storage-retail under refrigeration conditions (below $4^{\circ} \mathrm{C}$ ). The shelflife of the final product depends on numerous and

Acknowledgements: This work was supported by the projects TR 31075 and TR 31011, funded by the Ministry of Education, Science and Technological Development of the Republic of Serbia.

\footnotetext{
${ }^{1}$ Veterinary Institute "Subotica", Segedinski put 88, 24000 Subotica, Republic of Serbia;

2 Institute of Meat Hygiene and Technology, Kaćanskog 13, 11000 Belgrade, Republic of Serbia;

${ }^{3}$ University of Belgrade, Faculty of Veterinary Medicine, Department of Food Hygiene and Technology, Bulevar oslobođenja 18, 11000 Belgrade, Republic of Serbia;

${ }^{4}$ Scientific Veterinary Institute - Novi Sad, Rumenački put 20, 21000 Novi Sad, Repubic of Serbia.
}

Corresponding author: Pavlićević Nataša, natasakilibarda@gmail.com 
interrelated production parameters such as characteristic of raw material, process hygiene, salting method, salt level, smoking conditions, packaging in vacuum or under modified atmosphere, storing conditions, etc. Therefore, it is of great importance to optimize the individual processing steps involved in the production (Gallart-Jornet et al., 2007).

Salting of fish is the first step in the smoked fish production process, which is critical for the shelf life, good quality and yield of the final product. The preservative effect of salting is due to lowering of water activity $\left(\mathrm{a}_{\mathrm{w}}\right)$, (Jittinandana et al., 2002; Leroi and Joffraud, 2000), and thus reducing growth of many spoilage microorganisms (Horner, 1997, Rør$v i k, 2000)$. Dry salting is traditional but still the most common method of fish salting, whilst wet salting is rare in practice. In the latter case, e.g. with the Atlantic salmon fillet, the yield after salting was higher when more diluted brines were used, compared to usage of saturated brine and dry salting (GallarJornet et al., 2007). Nevertheless, it should be noted that, in modern times, fish products are relatively lightly salted. Both the salt content and the level of smoking applied vary among and within European countries (Cardial et al., 2001; Røra et al., 2004; Gallart-Jornet et al., 2007).

Smoking is a subsequent step in the smoked fish production process. The preservative effects of smoking depend also on other factors, including the composition and processing of raw material, and relative humidity (Kolodziejska et al., 2002). Smoke consists of numerous components including aldehydes, ketones, alcoholes, acids, hydrocarbons, esters and phenols (Doe et al., 1998; Shahidi, 1998; Guillèn and Errecalde, 2002; Guillén et al., 2006). Smoking extends the shelf-life of smoked fish as a result of the combined effects of dehydration, antimicrobial and antioxidant activity of some of smoke constituents (Doe et al. 1998; Horner, 1997, Leroy and Joffraud, 2000; Rørvik, 2000). Nevertheless, today, the main reason for smoking is manufacturing of fish products of desirable sensory properties, so "current" smoked fish products typically contain higher moisture and lower salt content (so lower $\mathrm{a}_{\mathrm{w}}$ ) than traditional, intensively smoked products.

Lightly salted and mildly heated smoked fish may contain bacteria - both spoilage organisms and foodborne pathogens - that, either survive the production process, or are present on the final product during the post-processing handling. Due to the fact that the temperature during the cold smoking never exceeds $28{ }^{\circ} \mathrm{C}$, it does not have any significant antimicrobial effect on pathogens in cold smoked fish (Gudbjornsdottir et al., 2010). Spoilage of fish, characterised by production of the spoilage odours and flavours, is due to metabolism of the microorganisms and the fish tissue autolytic enzymes having a major impact on textural deterioration (Hansen et al., 1996). In addition to salting and smoking effects, the shelf-life of smoked fish is affected by storage conditions. Differences in packaging- and temperature-related parameters throughout the storage period result in different product shelf-lives (Church and Parsons 1995; Cutter, 2002; Bugueño et al., 2003).

Decision taken by a producer regarding choice of smoked fish technology and related parameters to be used is influenced by the market demand and by the need for economical profit, as well. Furthermore, the choice of the process control parameters, such as duration of salting, concentration of brine and smoking temperature, is also influenced by specific characteristics of the final product that need to be achieved (Cardinal et al., 2004).

Good knowledge and appropriate selection of raw material is a prerequisite for effective process controls, good yield and required smoked fish quality (Beltrán and Moral, 1991; Røra et al., 1999; Cardinal et al., 2001; Birkeland et al., 2004). Frozen fish is frequently used for production of smoked fish products. This is particularly the case during periods when the fish catch exceeds the processing capacities, a situation occurring more often with smaller processors. Therefore, the main objective of this study was to determine the effect of freezing of raw material (fish) on the quality parameters (sensory, chemical and microbiological) of smoked trout fillets.

\section{Material and methods}

Fresh whole trout (average mass of $1 \mathrm{~kg}$ ) were obtained from the fishery Bočac, Banja Luka, Republic of Srpska - Bosnia and Herzegovina, and transported to the fish processing plant in special refrigerated vehicles, at $4^{\circ} \mathrm{C}$. The fish was subsequently slaughtered and separated into two groups: fish in the control group, which remained unfrozen, whilst those from the experimental group were frozen at $40^{\circ} \mathrm{C}$. Trout from the control group were rinsed in potable water and subsequently wet salted for $24 \mathrm{~h}$ in brine solution ( $9 \%$ salt) containing rosemary (quantum satis), in a temperature-controlled room $\left(4^{\circ} \mathrm{C}\right)$. After salting, before smoking, fish was drained for one hour at $20^{\circ} \mathrm{C}$ in smoking chambers. The smoking was performed in automated smoke chambers at the temperature of $28^{\circ} \mathrm{C}$ during the period of 8 hours. The smoke was produced from beech wood sawdust in a generator separated from the smoking chamber. Subsequently, fish was cooled (at $2^{\circ} \mathrm{C}$, for $10 \mathrm{~h}$ ), and then sliced (each slice $0.5 \mathrm{~cm}$ thickness; 
$150 \mathrm{~g}$ ). During the slicing, both, the skin and the rib bones were removed. Finally, the smoked trout fillets were vacuum packaged. Trout from the experimental group were frozen in a freezing tunnel (air temperature $-40^{\circ} \mathrm{C}$ ), placed individually in plastic bags and stored at $-20^{\circ} \mathrm{C}$. After 20 days, the fish were thawed by submersion in water $\left(10^{\circ} \mathrm{C}\right)$ for 5 hours and subjected to the processing in the same manner as described for the control group. The vacuum-packed, smoked trout fillets from both, control and experimental, groups were stored for 21 days at $4^{\circ} \mathrm{C}$ and sampled for analysis at $0,7^{\text {th }}, 14^{\text {th }}$ and $21^{\text {st }}$ days of the storage. Smoked trout fillets from both groups were analysed at $0,7^{\text {th }}, 14^{\text {th }}$ and $21^{\text {st }}$ days of storage for total viable count.

\section{Microbiological analysis}

\section{Sampling of fish skin during processing}

Skin of both, control and experimental, fish groups was sampled after the fish cleaning, evisceration, and cooling. Skin of the experimental fish was also sampled after thawing. From each group of samples, at each sampling point, a total of ten fish were sampled. Skin sample of $25 \mathrm{~cm}^{2}$ was excised from the location behind gills of each fish, kept at $4^{\circ} \mathrm{C}$, and analysed for the total viable count (TVC) of bacteria within $30 \mathrm{~min}$.

\section{Sampling of fish fillets}

From each group, at each sampling point, total of ten vacuum-packages of smoked trout fillets were sampled $0,7^{\text {th }}, 14^{\text {th }}$ and $21^{\text {st }}$ days of storage. Each sample, comprising of $10 \mathrm{~g}$ of the product, was kept at $4^{\circ} \mathrm{C}$ and analysed for the total viable count (TVC) of bacteria within $30 \mathrm{~min}$. Smoked trout fillets from both groups were analysed at $7^{\text {th }}, 14^{\text {th }}$ and $21^{\text {st }}$ days of the storage for total lactobacilli count.

\section{Microbiological methods}

Total viable count (TVC) of bacteria was determined according to Roberts et al. (1995). Briefly, each $10 \mathrm{~g}$ sample (skin or fillet) was homogenized in stomacher bag with $90 \mathrm{ml}$ of MRD (Maximum Recovery Diluent, Biolife, Italy) for 2 minutes, and then further decimal dilutions in MRD were prepared. From appropriate dilutions, volumes of $0.1 \mathrm{~mL}$ were surface plated on PCA agar plates (Plate Count Agar, Biolife, Italy), the plates were incubated for $72 \mathrm{~h}$ at $30^{\circ} \mathrm{C}$, and subsequently $\log _{10}$ $\mathrm{CFU} / \mathrm{cm}^{2}$ or g of sample was calculated. Lactobacilli count was determined according to Cook (1991). Briefly, samples were homogenized and decimally diluted in MRD in the same manner as described for
TVC. Volumes of $0.1 \mathrm{~mL}$ were surface plated onto MRS plates (MRS Agar with Tween 80, Biolife, Italy), and each was subsequently overlaid with $10 \mathrm{ml}$ of melted and cooled (to $45^{\circ} \mathrm{C}$ ) PCA agar to obtain microaerophylic conditions for growth of lactobacilli. The inoculated plates were incubated for $72 \mathrm{~h}$ at $30^{\circ} \mathrm{C}$ and subsequently $\log \mathrm{CFU} / \mathrm{g}$ of sample was calculated.

\section{Physicochemical and chemical analysis}

Chemical composition of samples was analysed at 0 day of storage according to standard methods. Moisture content was determined in $5 \mathrm{~g}$ of fish fillet samples by oven-drying at $105 \pm 1{ }^{\circ} \mathrm{C}$ until a constant weight was obtained (Anon, 1998). Fat content was determined using Soxhlet method, by extraction of fat by petrol ether from the dried sample, followed by distillation and drying of sample extract at $105 \pm 1{ }^{\circ} \mathrm{C}$ until constant weight was obtained (Anon, 1992a). Protein content was determined using Kjeldalh method with apparatus "Tecator" (Anon, 1992b). Ash content was determined by ashing the sample at $550^{\circ} \mathrm{C}$ until constant mass was obtained (Anon, 1999a). Total salt content was determined using Volhard method (Anon, 1999b). Salt content in water phase (SWP) was calculated from the corresponding total salt and water contents, using the equation:

$$
\mathrm{SWP}=\% \text { salt } * 100 / \% \text { salt }+\% \text { water }
$$

Water activity ( $a_{w}$ value) was calculated from the corresponding SWP value, using the equation (Gimenéz and Dalgaard, 2004):

$$
a_{\mathrm{w}}=1-0.0052471 \times \mathrm{SWP}-0.00012206 \times \mathrm{SWP}^{2}
$$

Ethanol content was determined in smoked trout samples (at $0,7^{\text {th }}, 14^{\text {th }}$ and $21^{\text {st }}$ days of storage) according to Beutler (1988), using standard enzyme kits based on alcohol dehydrogenase (Megazyme Inter. Ireland Lim).

\section{Sensory analysis}

Smoked trout fillets were subjected to the sensory analysis (at $0,7^{\text {th }}, 14^{\text {th }}$ and $21^{\text {st }}$ days of storage) by a panel of 14 trained evaluators. Selection of evaluators was performed according to ISO standard (Anon, 2002). Sensory evaluation was performed by quantitative descriptive analysis (Anon, 2001). The questionnaire included evaluation of 5 quality parameters. Each property was evaluated using a rating scale from 1 to 5 . Marks 1 to 5 indicated level of property expression (sensation of smell and taste to smoke, salinity, and tenderness) as well as 
acceptability of property (colour acceptability, total acceptability). The lowest expressed property, or the least acceptable property, was evaluated by 1 on a scale from 1 to 5, and the highest expressed property, or the most acceptable property, was evaluated by 5 on a scale from 1 to 5 .

\section{Statistical analysis}

For each sample and each parameter tested, at least 6 separate values were obtained. The results were statistically analysed (mean value, standard deviation, standard error, coefficient of variation and confidence interval for a variance), and statistical significance calculated ( $t$-test and analysis of variance at 0.01 and 0.05) using Graphpad Prism 4.0 statistical package.

\section{Results and discussion}

\section{Total viable count of bacteria on fish skin}

It is known that TVC on the fish skin just after the catch is highly variable, between $10^{2}$ and $10^{7}$ (i.e. 2 and $3 \log (0) \mathrm{CFU} / \mathrm{cm}^{2}$ (Liston, 1980). In the present study, the initial TVC (i.e. after slaughtering) on the skin was 3-4 $\log _{10} \mathrm{CFU} / \mathrm{cm}^{2}$. Subsequently,
TVC on the skin of the control fish group varied during manufacturing process from $3.53 \pm 0.98 \log _{10}$ $\mathrm{CFU} / \mathrm{cm}^{2}$ to $1.64 \pm 0.24 \log _{10} \mathrm{CFU} / \mathrm{cm}^{2}$ (Figure 1.), and in the final product it was significantly lower $(\mathrm{p}<0.01)$ than after slaughtering and evisceration. Similarly, TVC on the skin of the experimental group of fish varied from $3.79 \pm 0.57 \log _{10} \mathrm{CFU} / \mathrm{cm}^{2}$ to $1.07 \pm 0.40 \log _{10} \mathrm{CFU} / \mathrm{cm}^{2}$, and was significantly lower $(\mathrm{p}<0.01)$ in the final product as compared with initial stages of the processing. It could be presumed that a part of the TVC reductions were due to the removal of bacteria from the skin by washing, normally applied after evisceration. Importance of washing of fish after the first stage of fish processing was stressed by Kolodziejska et al. (2002), who observed significant TVC reduction after the washing.

During the later stages of the manufacturing process (i.e. after salting, smoking and cooling), TVC on the trout skin of the experimental group was significantly lower compared to TVC on the trout skin of the control group. After the draining stage there was no statistical sign determined $(p>0.05)$. It is well known that low temperatures inhibit activity of microorganisms and enzymes, but also reduce the count of microorganisms. Decrease of TVC on the trout skin of both the control and experimental group during manufacturing process was predominantly

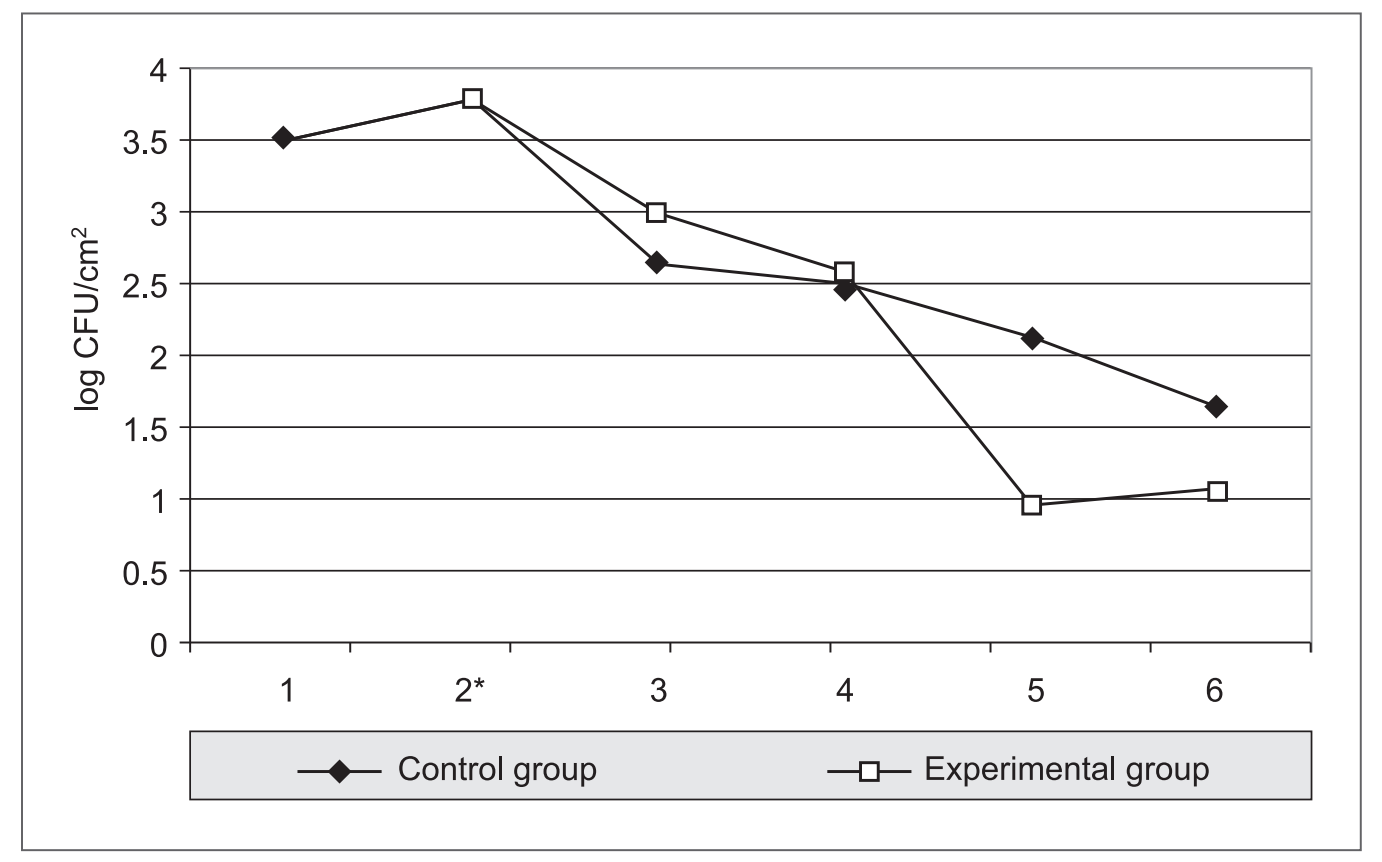

Figure 1. TVC on the skin of trout during manufacturing process $\left(\log \mathrm{CFU} / \mathrm{cm}^{2}\right)$

Note: Manufacturing phases - TVC on the fish skin 1-after slaughtering (control group only); 2 -after evisceration; 2 - after thawing; $\mathbf{3}$ - after salting; $\mathbf{4}$ - after draining; $\mathbf{5}$ - after smoking; $\mathbf{6}$ - after cooling

Slika 1. Ukupan broj bakterija na koži pastrmke u toku procesa proizvodnje

Napomena: faze u toku procesa proizvodnje - ukupan broj bakterija na površini ribe 1 - posle klanja (samo kontrolna grupa); 2 - posle eviseracije; $2^{*}$ - posle defrostracije; 3 - posle soljenja; 4 - posle ceđenja; 5 - posle dimljenja; 6 - posle hlađenja. 
due to the salt effect, both directly (its "toxicity"), (Goulas and Kontominas, 2005), and indirectly through decreasing of the water activity in fish meat ( $a_{w}$ value), which caused lowering of water content available to microorganisms. Initial decrease of $a_{w}$ value progressively inhibits bacterial growth, while further leading to growth cessation, however never to death of bacteria. Sodium chloride is dissolving in water and increases osmotic pressure. Ions also tend to bind with protein molecules. When there are no such bonds enzymes of microorganisms can effectively express their proteolytic activity. Previous reports indicated that, amongst processing-related factors, fish salting caused the largest decrease of TVC on fish skin (Kolodziejska et al., 2002). However, not all of the bacteria are equally affected by salting. Although TVC on the fish is lower after salting, some species can continue to grow even at higher salt concentrations (Skjervold et al., 2001). The results of the present study indicate that TVC on the skin of control group after salting $\left(2.64 \pm 0.14 \log _{10}\right.$ $\mathrm{CFU} / \mathrm{cm}^{2}$ ) was lower compared to TVC on the skin of experimental the group $\left(2.99 \pm 0.25 \log _{10} \mathrm{CFU} /\right.$ $\mathrm{cm}^{2}$ ) after salting. This phenomenon is likely to be due to pre-processing freezing of the experimental group, which probably enhanced the salt penetration into the fish tissues. Previous studies (Cardinal et al., 2001; Deng, 1977) demonstrated that salt penetrates better into fish previously frozen, and this is due to freezing-alterations of the tissue cell structure (Sigurgisladottir et al., 2000). After smoking, further decrease of the bacterial counts was observed (Figure 1), probably due to antimicrobial effects of the smoke. This explanation is supported by published data (Kolodziejska et al., 2002) indicating that smoking significantly reduces TVC on fish skin. In this study, TVC after smoking stage was $2.12 \pm 0.52 \log _{10} \mathrm{CFU} / \mathrm{cm}^{2}$ (control) and $0.98 \pm 0.23$ $\log _{10} \mathrm{CFU} / \mathrm{cm}^{2}$ (experimental). Comparably slightly higher TVCs (up to $3 \log _{10} \mathrm{CFU} / \mathrm{cm}^{2}$ ) on fish skin after smoking were reported in other studies (Hansen et al., 1995; Hansen et al., 1996; Hansen et al., 1998; Leroi et al., 1998; Dondero et al., 2004). On the other hand, it should be noted that post-smoking TVC in the experimental group was lower than postsmoking TVC in the control group (Fig. 1). This is likely to be the consequence of pre-processing freezing of the fish from the experimental group, which altered the tissue cell structure (Sigurgisladottir et $a l ., 2000)$ enabling better penetration of the antimicrobial smoke components.

\section{Chemical composition of the processed and finished smoked trout fillets}

Salt content in the experimental fillets was significantly higher than in the control fillets (Table 1). Similar differences in the salt content between salted fish that was fresh or frozen before salting were reported previously (Sigurgisladottir et al. 2000, Cardinal et al. 2001). These observations were probably due to better salt penetration into freezing-altered fish tissues. Similarly, SWP of the vacuum packaged fillets from the control group $(4.58 \pm 1.42 \%)$ was significantly lower $(p<0.01)$ then the SWP of the vacuum packaged fillets from the experimental group (5.93 $\pm 0.61 \%)$. Hansen et al. (1995) showed that increased SWP increases the shelf-life of vacuum packaged fish products. Calculated $\mathrm{a}_{\mathrm{w}}$ value in control fillets was 0.98 , whilst 0.97 in the experimental fillets. $a_{w}$ values in both groups, being not lower than 0.97, were insufficient to inhibit growth of microorganisms (Kolodziejska et al. 2002).

\section{General microflora of the smoked trout fillets}

Shelf-life of vacuum packaged smoked products depends on a number of factors, including initial contamination, manufacturing conditions, antimicrobial factors acting in the product,

Table 1. Chemical composition of the control and the experimental smoked trout fille

Tabela 1. Hemijski sastav kontrolnih i eksperimentalnih uzoraka fileta dimljene pastrmke

\begin{tabular}{|c|c|c|c|c|c|c|c|}
\hline \multirow[b]{2}{*}{ group/grupa } & \multicolumn{5}{|c|}{ content of $(\%) /$ sadržaj $(\%)$} & \multicolumn{2}{|c|}{ value of/vrednost } \\
\hline & $\begin{array}{c}\text { proteins/ } \\
\text { belančevine }\end{array}$ & $\begin{array}{l}\text { lipids/ } \\
\text { lipidi }\end{array}$ & salt/so & $\begin{array}{l}\text { moisture/ } \\
\text { vlaga }\end{array}$ & $\begin{array}{c}\text { ash/ } \\
\text { pepeo }\end{array}$ & SWP & $\begin{array}{c}\mathrm{a}_{\mathrm{w}} \text { value } \\
\mathrm{a}_{\mathrm{w}} \text { vrednost }\end{array}$ \\
\hline control/kontrolna & $21.08^{x} \pm 1.03$ & $2.08^{\mathbf{a}} \pm 0.46$ & $3.25^{\mathrm{x}} \pm 1.01$ & $71.00^{\mathbf{a}} \pm 2.43$ & $4.38^{x} \pm 0.92$ & $4.36^{\mathbf{x}} \pm 1.29$ & 0.98 \\
\hline $\begin{array}{l}\text { experimental/ } \\
\text { ekspeimentalna }\end{array}$ & $19.00^{\mathrm{y}} \pm 1.01$ & $1.98^{\mathbf{b}} \pm 0.65$ & $4.27^{\mathrm{y}} \pm 0.35$ & $72.24^{\mathbf{b}} \pm 1.93$ & $5.23^{y} \pm 0.36$ & $5.59^{\mathrm{y}} \pm 0.54$ & 0.97 \\
\hline
\end{tabular}

Note: Students' $t$-test - Means with different letter superscripts in the column are significantly different $(\mathrm{a}, \mathrm{b}-\mathrm{p}<0.05 ; \mathrm{x}, \mathrm{y}-\mathrm{p}<0.01) /$ Napomena: Studentov $t$-test - srednje vrednosti u koloni, koje su označene različitim slovima u eksperimentu, su signifikantno različite $(\mathrm{a}, \mathrm{b}-\mathrm{p}<0,05 ; \mathrm{x}, \mathrm{y}-\mathrm{p}<0,01)$ 
post-manufacturing handling and storage conditions (Hansen et al., 1995; Hansen et al., 1996; Leroi et al., 1998; Kolodziejska et al., 2002; Dondero et al., 2004).

Total viable count of bacteria in both the control and the experimental group, TVC in vacuum packaged trout fillets stored at $4{ }^{\circ} \mathrm{C}$ increased between 0 and $14^{\text {th }}$ day, but subsequently significantly decreased to the end of the 3-week storage (Fig. 2 ). At the very beginning (" 0 " sampling time) of the storage, TVC in the experimental fillets was lower than in the control fillets, but later (at $14^{\text {th }}$ and $21^{\text {st }}$ days) TVC differences between the control and the experimental fillets were statistically not significant. Final TVCs (day 21) were approx. 2-2.5 log $\mathrm{CFU} / \mathrm{g}$ in both groups, which could be considered as relatively low. Namely, numerous published data indicate that TVCs in vacuum packaged fish products often reach $10^{7}-10^{8} \mathrm{CFU} / \mathrm{g}$, e.g. Dondero et al. (2004) reported TVC as high as $10^{6} \mathrm{CFU} / \mathrm{g}$ in vacuum packaged trout fillets after 3 weeks of storage at $4^{\circ} \mathrm{C}$. Such a large difference in TVCs between different studies is probably caused by large differences in study conditions. It should be noted that in most EU countries related legislation does not limit TVC in vacuum packaged smoked fish products, although French legislation states $10^{6} \log _{10} \mathrm{CFU} / \mathrm{g}$ as maximum permissible TVC in such products (Cardinal et al., 2004). The observed changes of TVC in smoked fillets during storage were probably due to a number of interrelated factors, including microbial competition for nutrients and antagonism amongst the microflora that exists within any specific ecological niche (Gram, 1993). Nevertheless, no changes in TVC in vacuum packaged smoked trout were observed during 3-week storage in an earlier study (Kolodziejska et al., 2002), but the storage temperature $\left(2^{\circ} \mathrm{C}\right)$ was lower than in the present study $\left(4^{\circ} \mathrm{C}\right)$. On the other hand, Hansen et al. (1995) has reported comparably much higher TVC $\left(10^{8} \mathrm{CFU} / \mathrm{g}\right)$ in vacuum packaged smoked fish products stored for 21 day, but at somewhat higher temperature $\left(5^{\circ} \mathrm{C}\right)$ than in the present study. It should be noted that a number of published studies indicated that high TVC did not necessarily lead to spoilage of the product. For the vacuum packaged smoked fish products spoilage, much more relevant is the composition of the microflora and the activity of the specific spoilage microorganisms than TVC (Hansen et al., 1995; Hansen et al., 1996; Hansen et al., 1998; Leroi et al., 1998; Lyhs et al., 1999; Gonzáles-Rodrígez et al., 2002;

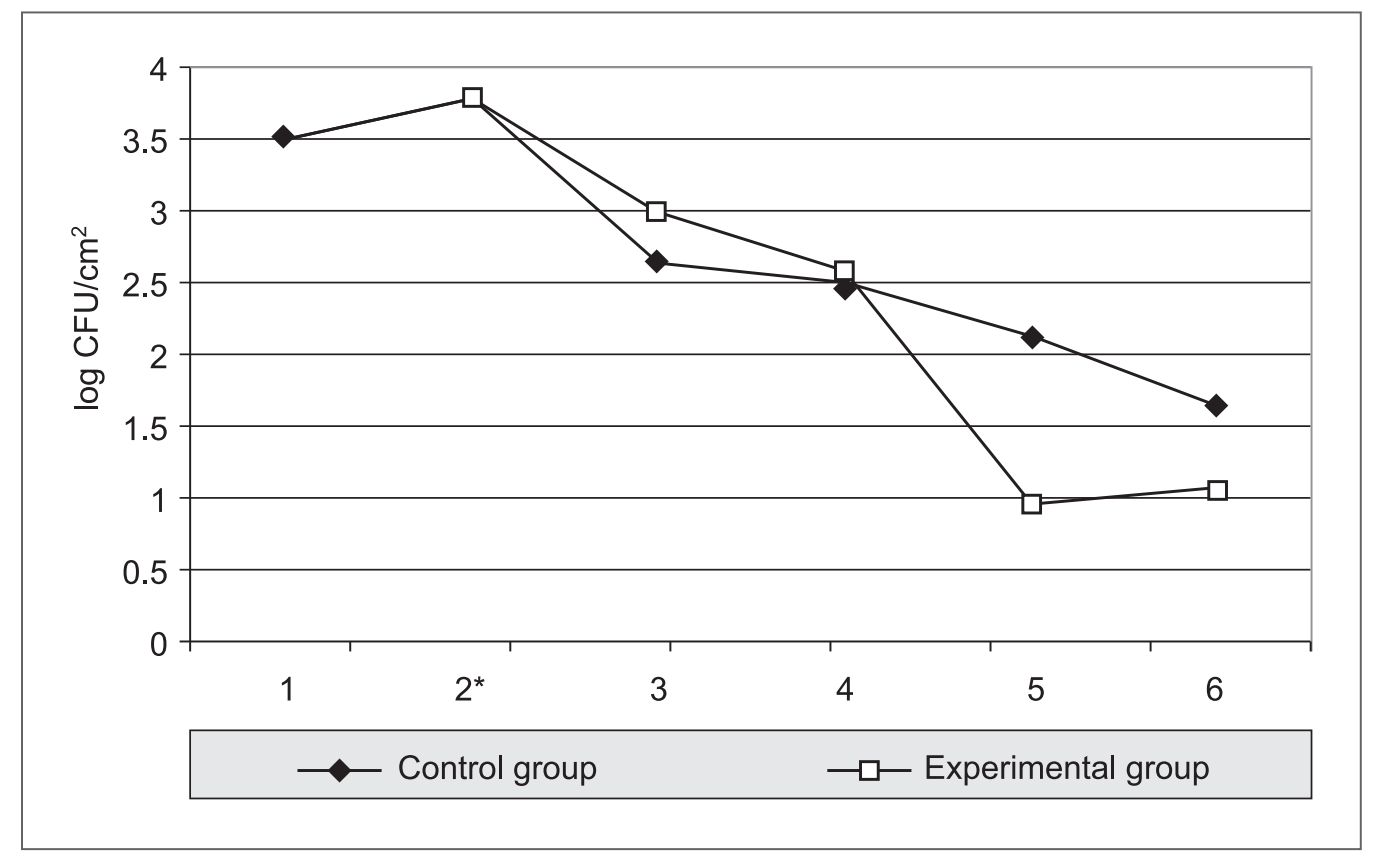

Figure 1. TVC on the skin of trout during manufacturing process $\left(\log \mathrm{CFU} / \mathrm{cm}^{2}\right)$

Note: Manufacturing phases - TVC on the fish skin $\mathbf{1}$ - after slaughtering (control group only); $\mathbf{2}$-after evisceration; $2 *$ after thawing; $\mathbf{3}$ - after salting; 4 - after draining; 5 - after smoking; $\mathbf{6}$ - after cooling

Slika 1. Ukupan broj bakterija na koži pastrmke u toku procesa proizvodnje

Napomena: faze u toku procesa proizvodnje - ukupan broj bakterija na površini ribe 1 - posle klanja (samo kontrolna grupa);

2 - posle eviseracije; $2^{*}$ - posle defrostracije; 3 - posle soljenja; 4 - posle ceđenja; 5 - posle dimljenja; 6 - posle hlađenja. 


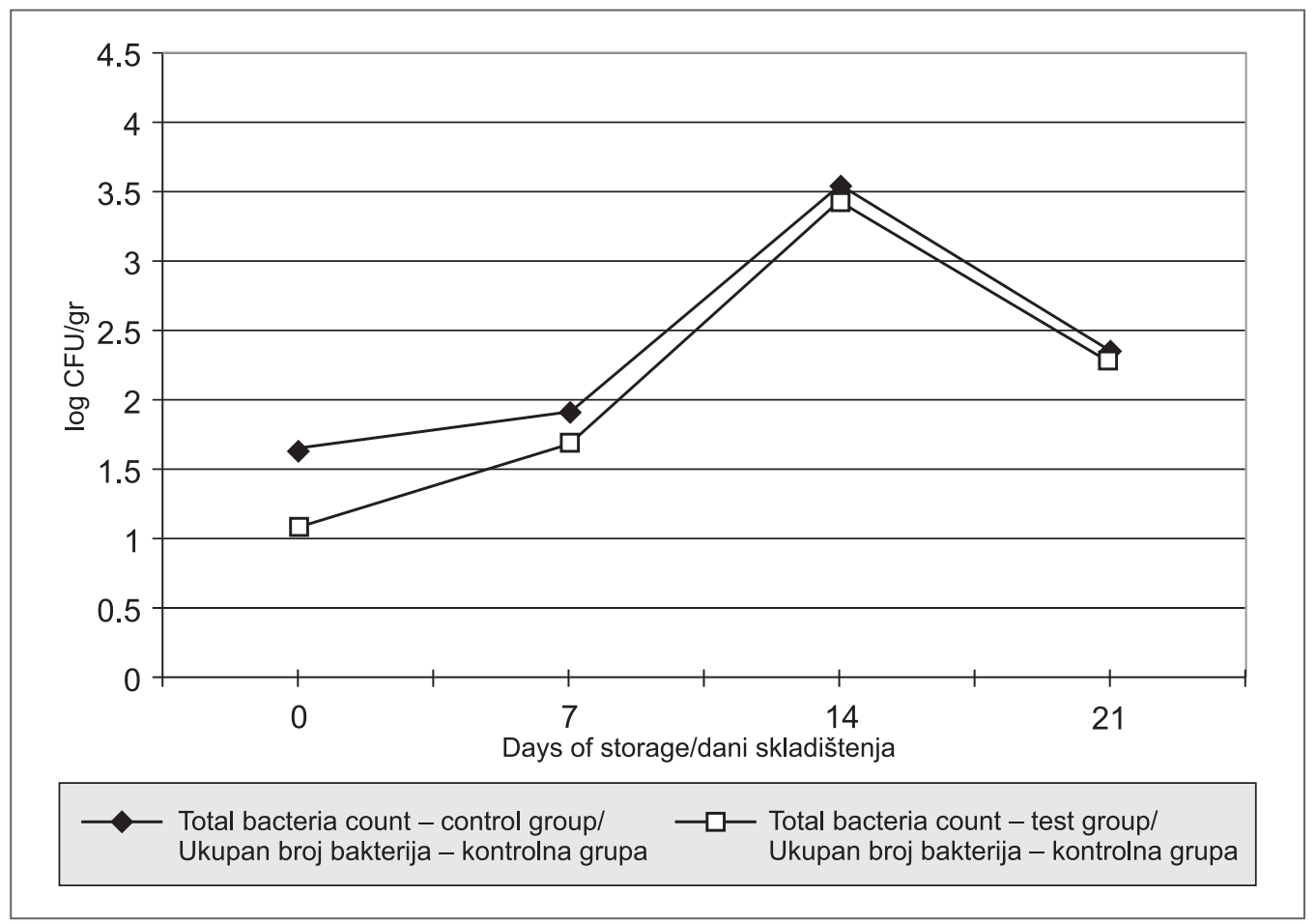

Figure 2. TVC in vacuum packaged smoked trout fillets during storage at $4{ }^{\circ} \mathrm{C}$

Slika 2. Ukupan broj bakterija u vakuum pakovanim dimljenim filetima pastrmke u toku skladištenja na $4^{\circ} \mathrm{C}$

Cardinal et al., 2004; Dondero et al., 2004; Espe et al., 2004).

\section{Lactobacilli count}

Smoked trout fillets from both groups were analysed for total lactobacilli count at $7^{\text {th }}, 14^{\text {th }}$ and $21^{\text {st }}$ days of the storage. The results indicated that lactobacilli (LAB) counts in both control and experimental vacuum packaged smoked trout fillets significantly increased between $7^{\text {th }}$ and $14^{\text {th }}$ day of storage at the $4^{\circ} \mathrm{C}$, and then decreased (Figure 3). LAB counts in the control fillets were significantly higher $(\mathrm{p}<0.01)$ than in the experimental fillets, at both $7^{\text {th }}$ and $14^{\text {th }}$ day, but LAB difference between the control and experimental fillets on $21^{\text {st }}$ day was not significant (approx. between 2.5 and $3 \log _{10} \mathrm{CFU} / \mathrm{g}$ ). In other studies, numerous authors investigated LAB count in vacuum packaged cold-smoked products, and $\mathrm{LAB}$ counts varied between $10^{3}-10^{8} \mathrm{CFU} / \mathrm{g}$ during 21 day of storage at $4^{\circ} \mathrm{C}$ (Hansen et al., 1998; Leroi et al., 1998; Dondero et al., 2004). Lactobacillus species are considered as the most prominent and the most important microorganisms for shelf-life of cold-smoked vacuum packaged fish products. Lactobacilli can inhibit growth of other bacteria by producing lactic acid and associated $\mathrm{pH}$ decrease and/or producing bacteriocins and/or competing for nutrient compounds, so their presence in vacuum packaged products can extend the shelf-life (Gram and Dalgaard, 2002). Among lactobacilli, dominant species in vacuum packaged smoked fish products are $L$. sakei, L. curvatus, L. homohiochii, L. plantarum, $L$. delbrueckii, L. casei, L. coryneformis, L. alimentarius (Gonzáles-Rodrígez et al., 2002). In addition, the second group of microorganisms most frequently isolated from vacuum packaged smoked fish products belong to Enterobacteriaceae: Proteus mirabilis, Proteus vulgaris and Serratia liquefaciens. The third group of microorganism that can be found in vacuum packaged smoked fish products belong to micrococci, with coagulase-negative staphylococci being predominant. Frangos et al. (2010) have observed that Lactobacilli and Enterobacteriaceae were also found to be a significant part of the microbial flora of trout fillets, irrespective of packaging and antimicrobial treatment. Leroi et al. (1998) have demonstrated that Gram-negative microflora is dominant during the first two weeks of vacuum packaged smoked fish storage, but it is subsequently replaced by Gram-positive microorganisms, predominantly lactobacilli. Overall, the results of this study indicated that hygienically obtained frozen fish is suitable raw material for production of microbiologically high quality smoked trout product. In this study, in the product that was frozen before manufacturing, both TVC and LAB counts during 


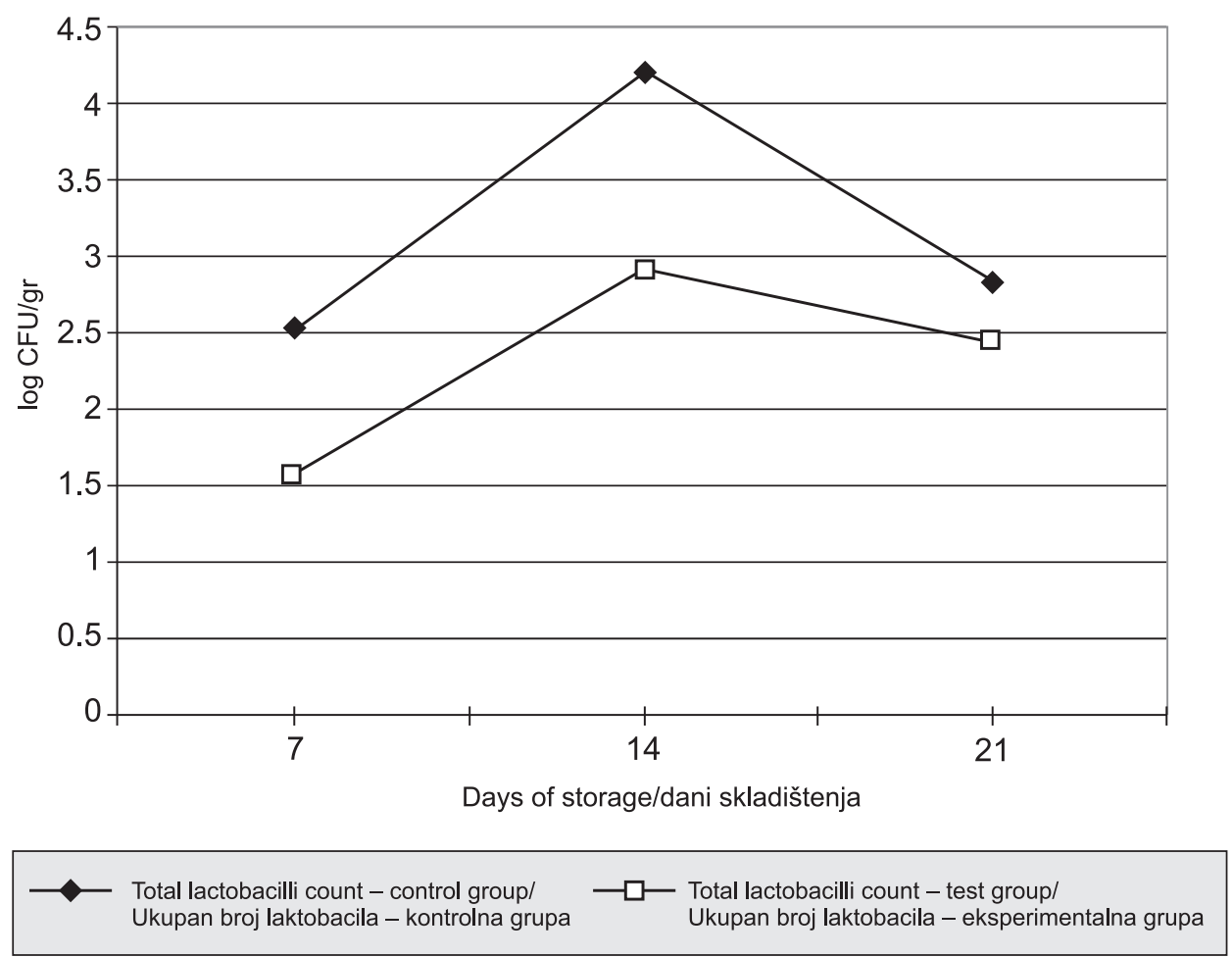

Figure 3. Lactobacilli (LAB) count in vacuum packaged trout fillets during storage at $4^{\circ} \mathrm{C}$

Slika 3. Broj laktobacila (LAB) u vakuum pakovanim filetima pastrmke u toku skladištenja na $4^{\circ} \mathrm{C}$

21-day chilled storage were lower than in the product produced from fresh fish.

Lactobacilli count versus ethanol content in the smoked trout fillets

Ethanol is a product of bacterial metabolism during anaerobic fermentation (glycolysis) and/or as a product of dezamination and decarboxylation of amino acids such as alanine (Huss, 1995). This suggests that ethanol could be used as an indicator of microbiological status of foodstuffs, as well as of their shelf-life. In the present study, the changes in ethanol content (Table 2) reflected the changes in LAB counts (Fig. 3) at corresponding times of the storage at $4^{\circ} \mathrm{C}$, in both the control and the experimental smoked fished fillets. This could indicate that ethanol content may be a useful indicator of the dynamics of LAB microflora in the product under given conditions. The association between ethanol content and LAB counts in vacuum packaged cold-smoked fish products was also reported by Hansen et al. (1995). However, Gonzáles-Rodrigez et al. (2002) claim that no correlation exists between ethanol and LAB counts, on one hand, and sensory assessment of the product, on the other.

Table 2. Ethanol content (mg/kg; mean values) in vacuum packaged smoked trout fillets stored at $4^{\circ} \mathrm{C}$ for 3 weeks

Tabela 2. Sadržaj etanola ( $\mathrm{mg} / \mathrm{kg}$; srednje vrednosti) u vakuum pakovanim filetima ribe pastrmke skladištenih na $4^{\circ} \mathrm{C}$ u toku tri nedelje

\begin{tabular}{lcccc} 
group/grupa & \multicolumn{4}{c}{ Day of storage/dani skladištenja } \\
\cline { 2 - 5 } & $\mathbf{0}$ & $\mathbf{7}$ & $\mathbf{1 4}$ & $\mathbf{2 1}$ \\
\hline control/kontrolna & 3.91 & 4.84 & 6.32 & 4.74 \\
experimental/eksperimentalna & 4.5 & 5.61 & 7.65 & 5.6 \\
\hline
\end{tabular}


Table 3. Evaluation scores of selected sensory properties of smoked trout

Tabela 3. Rezultati evaluacije odabranih organoleptičkih osobina dimljene pastrmke

\begin{tabular}{|c|c|c|c|c|c|c|c|c|c|c|}
\hline & \multicolumn{2}{|c|}{ Colour/Boja } & \multicolumn{2}{|c|}{$\begin{array}{c}\text { Tenderness/ } \\
\text { Nežnost, Mekoća }\end{array}$} & \multicolumn{2}{|c|}{$\begin{array}{c}\text { Sensation of smell and taste to } \\
\text { smoke/Osećaj mirisa i ukusa } \\
\text { na dim }\end{array}$} & \multicolumn{2}{|c|}{ Salinity/Slanost } & \multicolumn{2}{|c|}{$\begin{array}{c}\text { Total acceptability/Ukupna } \\
\text { prihvatljivost }\end{array}$} \\
\hline $\begin{array}{c}\text { days of } \\
\text { storage/dani } \\
\text { skladištenja }\end{array}$ & $\begin{array}{l}\text { Control group/ } \\
\text { kontrolna grupa }\end{array}$ & $\begin{array}{l}\text { Experimental } \\
\text { group/ } \\
\text { eksperimentalna } \\
\text { grupa }\end{array}$ & $\begin{array}{l}\text { Control group/ } \\
\text { kontrolna grupa }\end{array}$ & $\begin{array}{l}\text { Experimental } \\
\text { group/ } \\
\text { eksperimentalna } \\
\text { grupa }\end{array}$ & $\begin{array}{l}\text { Control group/ } \\
\text { kontrolna grupa }\end{array}$ & $\begin{array}{l}\text { Experimental } \\
\text { group/ } \\
\text { eksperimentalna } \\
\text { grupa }\end{array}$ & $\begin{array}{l}\text { Control group/ } \\
\text { kontrolna grupa }\end{array}$ & $\begin{array}{l}\text { Experimental } \\
\text { group/ } \\
\text { eksperimentalna } \\
\text { grupa }\end{array}$ & $\begin{array}{l}\text { Control group/ } \\
\text { kontrolna } \\
\text { grupa }\end{array}$ & $\begin{array}{l}\text { Experimental } \\
\text { group/ } \\
\text { eksperimentalna } \\
\text { grupa }\end{array}$ \\
\hline 0 & $4.36^{a} \pm 0.40$ & $4.04^{b} \pm 0.29$ & $4.23^{\mathrm{a}} \pm 0.42$ & $4.61^{b} \pm 0.49$ & $4.49 \pm 0.47$ & $4.43 \pm 0.35$ & $4.00^{x} \pm 0.29$ & $4.86^{y} \pm 0.38$ & $4.57 \pm 0.48$ & $4.27 \pm 0.40$ \\
\hline 7 & $4.23^{x} \pm 0.25$ & $4.46^{y} \pm 0.11$ & $4.39 \pm 0.42$ & $4.61 \pm 0.35$ & $4.68 \pm 0.32$ & $4.36 \pm 0.50$ & $3.93^{x} \pm 0.19$ & $4.71^{y} \pm 0.49$ & $4.50 \pm 0.48$ & $4.32 \pm 0.42$ \\
\hline 14 & $4.43^{x} \pm 0.18$ & $4.19 y \pm 0.23$ & $4.37 \pm 0.40$ & $4.14 \pm 0.29$ & $4.36 \pm 0.23$ & $4.21 \pm 0.26$ & $4.07^{x} \pm 0.19$ & $4.43^{y} \pm 0.19$ & $4.29^{x} \pm 0.24$ & $3.99^{\mathrm{y}} \pm 0.31$ \\
\hline 21 & $4.04 \mathrm{a} \pm 0.24$ & $3.62^{b} \pm 0.55$ & $4.02 \pm 0.26$ & $3.80 \pm 0.49$ & $4.01 \pm 0.26$ & $3.82 \pm 0.26$ & $3.61^{x} \pm 0.20$ & $4.21^{\mathrm{y}} \pm 0.27$ & $4.01 \pm 0.25$ & $3.77 \pm 0.31$ \\
\hline
\end{tabular}

Note: Students' $t$-test - Means with different superscript between control and experimental group are significantly different $(\mathrm{a}, \mathrm{b}-\mathrm{p}<0.05 ; \mathrm{x}, \mathrm{y}-\mathrm{p}<0.01) /$ Napomena: Studentov $t$-test - srednje vrednosti koje su označene različitim slovima, između kolona i eksperimantalnih grupa, su signifikanto različite $(a, b-p<0,05 ; x, y-p<0,01)$

\section{Sensory scoring of the smoked trout fillets}

Overall, mean scores of selected parameters of sensoriy properties of both control and experimental vacuum packaged smoked trout fillets decreased over the 3-week storage period, and the final scores were significantly lower than the initial ones (Table 3). This was expected, and decrease of sensory qualities of such products over their shelf life have been reported earlier (Goulas and Kontominas, 2005). In general, at any given evaluation time, no significant differences in the total acceptability between the control and the experimental fillets were observed. However, although non-significant, somewhat higher total acceptability scores were noted with the control smoked fillets produced from fresh (unfrozen) fish. Many consumers accentuate colour intensity as the main indicator of quality of smoked fish, as reported for German and French consumers (Torrissen et al., 2000). In the present study, mean scores for the colour of control fillets (days $0,7,14$ and 21) were significantly higher $(p<0.05$ to $p<0.01)$ than those of the experimental fillets Table 3 ). Similar results have been reported before (Cardinal et al., 2001), that smoked fish produced from pre-processing frozen fish had less intense colour than in case when the fish was not frozen before processing. In contrast, some other authors (Leroi et al., 2001) have reported no significant colour variations in smoked fish (stored 3 weeks at $4{ }^{\circ} \mathrm{C}$ ) attributable to pre-processing fish freezing. It should be considered that some other factors could also affect the colour scoring of the smoked fish. For example, a positive correlation between fat content and colour intensity of smoked products has been reported (Røra et al., 1999). Mean scores for tenderness were significantly higher in the control fillets than in the experimental fillets only at day 0 of the storage, but no significant differences were observed on days 7, 14 and 21 (Table 3). It is likely that the initial difference in the tenderness was caused by the corresponding differences in the salt content in the products. Mollifying of fish is a consequence of autolytic processes due to catepsin activity, and increased salt content inhibits activity of catepsins, thus decreasing mollifying (Reddi et al., 1972). On the other hand, some other authors (Cardinal et al., 2001) have reported that smoked fish products obtained from frozen raw material were softer. Mean scores for salinity were significantly higher $(\mathrm{p}<0.01)$ in the experimental smoked fillets than in the controls throughout the 3 -week storage period at $4^{\circ} \mathrm{C}$ (Table 3). The main reason for that was better penetration of salt in tissue cells altered by freezing, as indicated before. In some other studies, smoked fish products made from frozen fish also had more intense taste of salinity than the products made from fresh fish (Cardinal et al., 2001). The authors considered that freezing-altered tissue texture stimulated salinity perception causing impression of the salt content being higher than actual.

\section{Conclusions}

As far as general microflora (TVC and LAB) is concerned, cold smoked, vacuum-packaged trout fillets produced from pre-processing frozen fish had superior microbiological characteristics compared to those produced from pre-processing unfrozen fish. Freezing-alterations of the fish tissues enabled better penetration of salt leading to higher salt-in-water content and lower water activity which, in turn, 
contributed to the extended shelf life of the product. At the same time, pre-processing freezing had no significant detrimental effect on the total sensory acceptability of the smoked vacuum-packaged trout fillets, neither initially or after 3-week cold-storage.
Overall, the results of the present study demonstrated that pre-processing freezing of trout is suitable and, in times of large catches, even recommendable step in smoked trout production, at least for smaller processors.

\section{References}

Anon, 1992a. SRPS ISO 1442:1992 - Meat and meat products - Determination of total fat content.

Anon, 1992b. SRPS ISO 937:1992 - Meat and meat products Determination of nitrogen content.

Anon, 1998. SRPS ISO 1442:1998. Meat and meat products Determination of moisture content.

Anon, 1999a. SRPS ISO 936:1999 - Meat and meat products Determination of total ash.

Anon, 1999b. SRPS ISO 1841-1:1992 - Meat and meat products - Determination of chloride content - Part 1: Volhard method.

Anon, 2001. SRPS ISO 6564:2001 - Sensory analysis - Methodology - Flavour profile methods.

Anon, 2002. SRPS ISO 8586-1:2002 - Sensory analysis - General guidance for the selection, training and monitoring of assessors - Part 1: Selected assessors.

Anon, 2009. FAO: ftp://ftp.fao.org/FI/STAT/summary/default.htm

Babić J., Milijašević M., Baltić Ž. M., Spirić A., Lilić S., Jovanović J., Đorđević M., 2009. Uticaj različitih smeša gasova na očuvanje senzorskih svojstava odrezaka šarana (Cyprinus carpio). Tehnologija mesa, 50, 5-6, 328-334.

Beltrán A., Moral A., 1991. Changes in fatty acid composition of fresh and frozen sardine (Sardina pilchardus W.) during smoking. Food Chemistry, 42, 99-109. doi: 10.1016/0308-8146(91)90010-L.

Beutler H.O., 1988. Ethanol. In: Methods of Enzymatic Analysis (Bergmeyer, H. U. ed.), VCH Publishers (UK) Ltd., Cambridge, UK 3rd ed., Vol. VI, 598-606.

Birkeland S., Røra A. M. B., Skara T., Bjerkeng B., 2004. Effects of cold smoking procedures and raw material characteristics on product yield and quality parameters of cold smoked Atlantic salmon (Salmo salar L.) fillets. Food Research International, 37, 273-286. doi: 10.1016/j. foodres.2003.12.004.

Bugueño G., Escriche I., Matrínez-Navarrete N., del Mar Camacho M., Chiralt A., 2003. Influence of storage conditions on some physical and chemical properties of smoked salmon (Salmo salar) processed by vacuum impregnation techniques. Food Chemistry, 81,1, 85-90. doi: 10.1016/S0308-8146(02)00381-3

Cardinal M., Knockaert C., Torrissen O., Sigurgisladottir S., Mórkóre T., Thomassen M., Vallet J. L., 2001. Relation of smoking parameters to the yield, colour and sensory quality of smoked Atlantic salmon (Salmo salar). Food Research International, 34, 537-550. doi: 10.1016/ S0963-9969(01)00069-2.

Cardinal M., Gunnlaugsdottir H., Bjoernevik M., Ouisse A., Vallet J. L., Leroi F., 2004. Sensory characteristics of cold-smoked Atlantic salmon (Salmo salar) from European market and relationships with chemical, physical and microbiological measurements. Food Research International, 37, 2, 181-193. doi: 10.1016/j.foodres.2003.12.006.
Church I. J., Parsons A. L., 1995. Modified Atmosphere Packaging Technology: A Review, Journal of the Science of Food and Agriculture, 67, 143-152. doi: 10.1002/ jsfa.2740670202.

Cook, 1991. Microbiological method for the meat industry, MIRINZ, Second Edition of Meat Industry Research Institute of New Zealand, Hamilton, New Zealand.

Cutter C. N., 2002. Microbial control by packaging: A review. Critical Reviews in Food Science and Nutrition, 42, 2, 151-161. doi: 10.1080/10408690290825493.

Deng J. C. 1977. Effects of freezing and frozen storage on salt penetration into fish muscle immersed in brine. Journal of Food Science and Technology, 32, 159-168. doi: 10.1111/ j.1365-2621.1977.tb01495.x

Doe P. E., Sikorski Z., Haard N., Olley J., Sun Pan B., 1998. Basic Principals. In Fish Drying and Processing. Production and Quality. Peter E. Doe (Ed.) Technomic Publishing Co., Lancaster, 13-46.

Dondero M., Cisternas F., Carvajal L., Simpson R., 2004. Changes in quality of vacuum-packed cold-smoked salmon (Salmo salar) as a function of storage temperature. Food Chemistry, 87, 543-550. doi: 10.1016/j.foodchem.2004.01.005.

Espe M., Kiessling A., Lunestat B., Torrissen O., Røra A. B. 2004. Quality of cold smoked salmon collected in one French hypermarket during a period of 1 year. Lebensm.-Wiss. u.-Technol., 37, 627-638. doi: 10.1016/j. lwt.2004.01.008.

Espe M., Nortvedt R., Lie Ø., Hafsteinsson H., 2001. Atlantic salmon (Salmo salar, L.) as raw material for smoking industry. I: effect of different salting methods on the oxidation of lipids. Food Chemistry, 75, 411-416. doi:10.1016/ S0308-8146(01)00228-X.

Frangos L., Pyrgotou N., Giatrakou V., Ntzimani A., Savvaidis I. N., 2010. Combined effects of salting, oregano oil and vacuum-packaging on the shelf-life of refrigerated trout fillets. Food Microbiology, 27, 115-121. doi:10.1016/j.fm.2009.09.002.

Gallart-Jornet L., Barat J. M., Rustad T., Erikson U., Escriche I., Fito P., 2007. Influence of brine concentration on Atlantic salmon fillet salting. Journal of Food Engineering, 80, 267-27. doi: 10.1016/j.jfoodeng.2006.05.018.

Gimenéz B., Dalgaard P., 2004. Modelling and predicting the simultaneous growth of Listeria monocytogenes and spoilage microorganisms in cold-smoked salmon. Journal of Applied Microbiology, 96, 96-109. doi: 10.1046/j. 1365-2672.2003.02137.x.

Gonzáles-Rodrígez M. N., Sanz J., Santos J. A., Otero A., García-López M. L., 2002. Numbers and types of microorganisms in vacuum-packed cold-smoked freshwater fish at the retail level. International Journal of Food Microbiology, 77, 161-168. doi: 10.1016/S0168-1605(02)00048-X. 
Goulas A. E., Kontominas M. G., 2005. Effect of salting and smoking-method on the keeping quality of chub mackerel (Scomber japonicus): biochemical and sensory attributes. Food Chemistry, 93, 511-520. doi: 10.1016/j.foodchem.2004.09.040.

Gram L., 1993. Inhibitory effects against pathogenic and spoilage bacteria of Pseudomonas strains isolated from spoiled and fresh fish. Applied and Environmental Microbiology, 59, 2197-2023.

Gram L., Dalgaard P., 2002. Fish spoilage bacteria-problems and solution. Current Opinion in Biotechnology, 13, 262-266. doi: 10.1016/S0958-1669(02)00309-9.

Gudbjornsdottir B., Jonsson A., Hafsteinsson H., Heinz V., 2010. Effect of high pressure processing on Listeria spp. and on the textural and microstructural properties of cold smoked salmon. Food Science and Technology, 43, 366-374. doi: 10.1016/j.lwt.2009.08.015.

Guillén M. D., Errecalde M. C., 2002. Volatile components of raw and smoked black bream (Brama raii) and rainbow trout (Oncorhynchus mykiss) studied by means of solid phase microextraction and gas chromatography/mass spectrometry. Journal of the Science of Food and Agriculture, 82, 9, 945-952. doi: 10.1002/jsfa. 1128

Guillén M. D., Errecalde M. C., Salmerón J., Casas C., 2006. Headspace volatile components of smoked swordfish (Xiphias gladius) and cod (Gadus morhua) detected by means of solid phase microextraction and gas chromatography-mass spectrometry. Food Chemistry, 94, 151-156. doi: 10.1016/j.foodchem.2005.01.014.

Hansen L. T., Gill T., Huss H. H., 1995. Effects of salt and storage temperature on chemical, microbiological and sensory changes in cold-smoked salmon. Food Research International, 28, 123-130. doi: 10.1016/0963-9969(95)90795-C.

Hansen L. T., Gill T., Røntved S. D., Huss H. H., 1996. Importance of autolysis and microbiological activity of quality of cold-smoked salmon. Food Research International, 29, 181-188. doi: 10.1016/0963-9969(96)00003-8

Hansen L. T., Røntved S. D., Huss H. H., 1998. Microbiological quality and shelf life of cold-smoked salmon from three different processing plants. Food Microbiology, 15, 137-150. doi: 10.1006/fmic.1997.0148.

Horner W. F. A., 1997. Salting In: Fish Processing Technology: Preservation of Fish, Curing. Hall, G.M (ed), Chapman \& Hall Publishers. UK, 32-72

Huss H. H., 1995. Quality and quality chages in fresh fish. FAO Fisheries Technical Paper, Roma.

Jittinandana S., Kenney P. B., Slider S. D., Kiser R. A. 2002. Effect of brine concentration and brining time on quality of smoked rainbow trout fillets. Journal of Food Science, 67, 6, 2095-2099. doi: 10.1111/j.1365-2621.2002. tb09507.x

Kolodziejska I., Niecikowska C., Januszewska E., Sikorski Z. E., 2002. The Microbial and Sensory Quality of Mackerel Hot Smoked in Mild Conditions. Lebensm.-Wiss. u Technol., 35, 87-92. doi: 10.1006/ fstl.2001.0824

Leroi F., Joffraud J., Chevalier F., Cardinal M., 1998. Study of the microbial ecology of cold-smoked salmon during storage at $8^{\circ} \mathrm{C}$. International Journal of Food Microbiology, 39, 111-121. doi: 10.1016/S0168-1605(97)00126-8.
Leroi F., Joffraud J., 2000. Salt and smoke simultaneously affect chemical and sensory quality of cold-smoked salmon during $5^{\circ} \mathrm{C}$ storage predicted using factorial design. Journal of Food Protection, 63, 9, 1222-1227.

Leroi F., Joffraud J., Chevalier F., Cardinal M., 2001. Research of quality indices for cold-smoked salmon using a stepwise multiple regression of microbiological counts and physics-chemical parameters. Journal of Applied Microbiology, 90, 578-588. doi: 10.1046/j.13652672.2001.01283.x

Liston J., 1980. Microbiology in fishery science. In: Connell,J.J. (ed.) Advances in fishery science and technology. Fishing News Books Ltd., Farnham, England, 138-157.

Lyhs U., Bjőrkroth J., Korkeala H., 1999. Characterisation of lactic acid bacteria from spoiled, vacuum-packed, coldsmoked rainbow trout using ribotyping. International Journal of Food Microbiology, 52, 77-84. doi: 10.1016/ S0168-1605(99)00117-8.

Milijašević M., Babić J., Baltić Ž. M., Spirić A., Velebit B., Borović B., Spirić D., 2010. Uticaj različitih smeša gasova na promene nekih mikrobioloških i hemijskih parametara u odrescima šarana (Cyprinus carpio) upakovanih u modifikovanu atmosferu. Tehnologija mesa, 51, $1,66-70$.

Reddi P. K., Constantinides S. M., Dymsza H. A., 1972. Catheptic activity of fish muscle. Journal of Food Science, 37, 643-8. doi: 10.1111/j.1365-2621.1972.tb02716.x.

Roberts D., Hooper W., Greenwood M., 1995. Practical Food Microbiology, second edition, Public Health Laboratory Service, London.

Røra A. M., Kvale A., Mørkøre T., Rørvik K., Hallbjoørn S., Thomassen S., 1999. Process yield, colour and sensory quality of smoked Atlantic salmon (Salmo salar) in relation to raw material characteristics. Food Research International, 31, 601-609. doi: 10.1016/S0963-9969(99)00034-4.

Røra A. M., Furuhaug R., Fjæra S. O., Skjervold P.O., 2004. Salt diffusion in pre rigor filleted Atlantic salmon. Aquaculture, 232:255-263. doi:10.1016/S00448486(03)00460-5

Rørvik L. M., 2000. Listeria monocytogenes in the smoked salmon industry. International Journal of Food Microbiology, 62, 183-190. doi: 10.1016/S0168-1605(00)00334-2.

Shahidi F., 1998. Flavour of Meat, Meat products and Seafoods. Blackie academic \& Professional, 342-353.

Sigurgisladottir S., Sigurdardottir M. S., Torrissen O. J., Vallet J. L., Hafsteinsson H., 2000. Effects of different salting and smoking processes on the microstructure, the texture and yield of Atlantic salmon (Salmo salar) fillets. Food Research International, 33, 847-855. doi: 10.1016/ S0963-9969(00)00104-6.

Skjervold P. O., Fjæra S. O., Ǿstby P. B., Einen O., 2001. Live chilling and crowding stress before slaughter of Atlantic salmon (Salmo salar). Aquaculture, 19, 265-280. doi: 10.1016/S0044-8486(00)00447-6.

Torrissen O. J., Bencze-Røra A. M., Nortvedt R., Espe M., Jørgensen L., Sørensen N. K., Olsen S.O., 2000. In: Program \& Abstract. Atlantic salmon-quality and market responses (pp. 75). The Ninth International Symposium on Nutrition \& Feeding in Fish. May 21-25, 2000, Miyazaki, Japan. 


\title{
Uticaj prethodne obrade pastrmke zamrzavanjem na karakteristike fileta dimljene pastrmke
}

\author{
Pavlićević Nataša, Đorđević Vesna, Dimitrijević Mirjana, Karabasil Neđeljko, Baltić Ž. Milan, \\ Bošković Marija, Petrović Jelena
}

S a ž e t a k: U situaciji kada su kapaciteti za proizvodnju i dalji tretman dimljene ribe nedovoljni potrebno je da se sveža riba tokom sezone izlova zamrzne i da se preradi kasnije, kada se sezona završi. To je bio razlog zašto je za cilj naših istraživanja postavljeno da se ispitaju efekti zamrzavanja na određene parametre kvaliteta dimljene ribe. Za eksperiment, pastrmke su bile podeljene u dve grupe: kontrolna grupa, koju je sačinjavala sveža riba i eksperimentalna grupa, koju je sačinjavala smrznuta riba. Tokom procesa proizvodnje ispitan je ukupan broj bakterija, a na kraju procesa, u konačnom proizvodu (vakuum-pakovana hladno dimljena pastrmka), određeni su hemijski parametri. U toku skladištenja proizvoda na $+4^{\circ} \mathrm{C}$ tokom 21 dan, u redovnim intervalima su izvršena mikrobiološka, fizičko-hemijska i senzorna ispitivanja. Generalno, rezultati ovih istraživanja su pokazali da je prethodna obrada pastrmke zamrzavanjem pogodna $i$, u vreme velikih izlova, čak i preporučljiv korak u proizvodnji dimljene pastrmke, bar što se tiče manjih proizvođača. Ključne reči: hladno dimljenje, skladištenje, kvalitet.

Paper received 10.09.2013.

Paper accepted: 13.09.2013. 